\title{
PENGGUNAAN SINGKATAN DAN AKRONIM DALAM BERITA KRIMINAL HARIAN TRIBUN JAMBI PADA BULAN MARET 2019
}

\author{
Avra Jumasha Refri Asih ${ }^{1}$, Uli Wahyuni ${ }^{2}$ \\ Program Studi Pendidikan Bahasa dan Sastra Indonesia, \\ Fakultas Keguruan dan Ilmu Pendidikan, Universitas Batanghari, \\ Jambi \\ avrajumasyahra@gmail.com \\ Uli09yumna@gmail.com
}

\begin{abstract}
The purpose of this research is to describe the abbreviation form and acronym used in the criminal daily news of Tribun Jambi March edition 2019. This type of research is a qualitative descriptive. The data are taken from the daily issue of Tribun Jambi March edition 2019. The technique of collecting the data is documentation. The results show that, from all 16 data, there are only 4 forms of acronyms and 1 abbreviation form were found in the daily criminal news of Tribun Jambi March edition 2019. From all three forms of the acronym, there is 2 quotations which represents the first letter of the acronym; there is 7 quotations which represents the first two-letter retention of each component; theere is 10 quotations which represents the first three-letter for each component; and there are 12 quotations which represents the retention of many letters and syllables that are difficult to formulate. While on the abbreviation, it is found only the first letter retention of each component as much as 51 quotations.
\end{abstract}

Keywords: Abbreviation, Acronym, Tribun Jambi Daily News

\footnotetext{
${ }^{1}$ Mahasiswa Program Studi Pendidikan Bahasa dan Sastra Indonesia, Fakultas Keguruan dan Ilmu Pendidikan, Universitas Batanghari, Jambi

${ }^{2}$ Dosen Program Studi Pendidikan Bahasa dan Sastra Indonesia, Fakultas Keguruan dan Ilmu Pendidikan, Universitas Batanghari, Jambi
}

Penggunaan Singkatan dan Akronim dalam Berita Kriminal Harian Tribun Jambi Pada Bulan Maret 2019 


\section{PENDAHULUAN}

Bahasa adalah alat yang sistematis untuk menyampaikan gagasan dan perasaan (Rahima dan M.Juanda, 2019:10). Fenomena ini menjadi dasar untuk mengungkapkan ide, gagasan, isi pikiran, keinginan maupun perasaan seseorang kepada orang lain dengan menggunakan bahasa Sebagai makhluk sosial, manusia senantiasa berhubungan dengan manusia yang lain. Manusia tidak dapat hidup tanpa bantuan dan berinteraksi dengan orang lain. Interaksi tersebut dapat dilakukan melalui berbagai cara. Cara berinteraksi yang paling utama adalah berkomunikasi dengan memanfaatkan bahasa sebagai media. Sebagai alat komunikasi bahasa merupakan seperangkat lambang bunyi yang bersifat konvensional, atbitrer, mempunyai makna, dan dihasilkan oleh alat ucap manusia. Seorang penutur dalam mengimplementasikan fungsi bahasa sebagai alat komunikasi jelas akan memakai tanda-tanda, bunyi-bunyi, gesture yang berkaitan dengan mimik berdasarkan kesepakatan bersama, sehingga komunikasi dapat dipahami bersama antara penutur dan penanggap tuturnya. (Rahima, 2002, 12).

Fungsi bahasa yang paling mendasar ialah sebagai alat komunikasi (Rofii dan Hasibuan, 2019:16). Penggunaan bahasa dalam berkomunikasi ada dua macam yaitu bahasa lisan dan bahasa tulis. Bahasa lisan berbentuk komunikasi secara langsung, bahasa yang dihasilkan oleh alat ucap manusia, bahasa lisan juga ekspresif dimana mimik, intonasi, dan gerakan tubuh dapat bercampur menjadi satu untuk mendukung komunikasi yang dilakukan. Sedangkan bahasa tulis juga sangat diperlukan untuk menginspirasikan sebuah ide atau gagasan yang menginformasikan melalui karya tulis
(Widarmanto, 2015:11). Bahasa tulis juga terdapat pada media cetak, seperti: surat, majalah, koran.

Koran sebagai media cetak memiliki banyak nama seperti Kompas, Repbulika, Tempo, Jambi Ekspres, Jambi Independent, dan Tribun Jambi. Koran merupakan salah satu media informasi bagi masyarakat. Berita pada koran menggunakan variasi dalam penulisannya. Penggunaan variasi bahasa dalam penulisan berita pada koran menjadi ciri tersendiri bagi koran tersebut. Banyak koran menggunakan bahasa yang berbeda-beda, sehingga koran tersebut dapat mudah diketahui penerbit dan sumbernya. Penggunaan bahasa dalam koran juga cenderung singkat dan hemat. Koran dapat memberikan berita yang lebih akurat dan jelas, baik itu berita ekonomi, politik, kebudayaan, olahraga sampai kependidikan. Penulisan bahasa di dalam media sangat penting memperhatikan penggunaan rangkaian kata-kata, agar pembaca menjadi paham dengan berita yang disampaikan. Penulisan berita dalam bentuk wacana pada koran ini menggunakan rangkaian kata-kata yang di dalam ilmu bahasa disebut morfologi. Rofii dan Franscy (2018:7) mengatakan bahwa in the morphology, described the process of word formation, said forming tool, class of words, meanings of words, as well as changes in the sound produced by the morphological process"Morfologi ialah kajian ilmu bahasa yang membahas mengenai seluk-beluk bentuk kata" (Ramlan, 2001:21).

Di dalam morfologi ini mencakup tentang abreviasi yang mana pengertian abreviasi ialah proses pemenggalan kata, dan di dalam abreviasi akan dibahas mengenai singkatan dan akronim. Penggunaan kata-kata dalam media seringkali menggunakan akronim. 
Akronim ialah pemendekan pada kata dan suku kata. Penggunaan singkatan dan akronim yang berantakan atau tidak terstruktur akan menyebabkan pemahaman menjadi bias oleh pembaca. Hal ini akan mengakibatkan kebingungan bagi pembaca.

Penulisan akronim di dalam koran dapat dipakai dalam berbagai bidang pemberitaan. Sebagaimana diketahui bahwa koran menuangkan berita-berita yang berkaitan dengan sosial, iklan, olahraga, kebudayaan, pendidikan dan tindakan kriminal. Berita kriminal adalah berita atau laporan mengenai kejahatan, berita yang masuk dalam berita kejahatan diantaranya adalah pembunuhan, penipuan, pemerkosaan, pencurian, narkoba, tawuran, penganiayaan, korupsi, dan sebagainya yang melanggar hukum. Penggunaan singkatan dan akronim seringkali terdapat dalam berita kriminal pada koran. Salah satu fenomena penggunaan singkatan dan akronim yang terdapat di dalam berita kriminal pada koran, contohnya: curanmor (pencurian kendaraan bermotor), pemkot (pemerintah kota), polda (kepolisian daerah), HAM (hak asasi manusia).

Tribun Jambi merupakan salah satu pers daerah yang dikelola oleh Kompas Gramedia. Perusahaan ini merupakan salah satu usaha Indonesia yang bergerak di bidang media masa. Kompas Gramedia didirikan oleh PK Ojong dan Jakop Oetama pada tanggal 28 Juni 1965. Koran harian Tribun Jambi terbit pada pagi hari. Untuk mendapatkan koran Tribun Jambi ini pun cukup mudah dan tentunya dengan harga yang terjangkau.

Pada berita kriminal Tribun Jambi, banyak ditemukan singkatan dan akronim. Dibandingkan dengan majalah, harga koran Tribun Jambi jauh lebih murah. Pembaca koran harian Tribun
Jambi ini tidak terbatas pada usia teryentu, baik dari kalangan mahasiswa, pengusaha, pejabat, sampai ibu rumah. Di dalam koran harian Tribun Jambi berisikan berita kriminal mulai dari pembunuhan, perampokan, korupsi, narkoba dan lain-lain, yang menarik untuk dikaji dari tinjauan analisis wacana, khususnya pada pola penggunaan akronimnya.

\section{METODE PENELITIAN}

Metode yang digunakan dalam penelitian ini adalah metode deskriptif kualitatif. "Metode deskriptif adalah suatu metode dalam pencarian fakta status kelompok manusia, suatu objek, suatu kondisi, suatu sistem pemikiran ataupun suatu peristiwa pada masa sekarang dengan interprestasi yang tepat" (Sedarmayanti dan Hidayat, 2011:33). Tujuan penelitian deskriptif adalah untuk membuat deskripsi, gambaran, secara sistematis, faktual, dan akurat mengenai fakta-fakta, sifat-sifat serta hubungan antara fenomena yang diselidiki. Penelitian ini tidak mempresentasikan angka, tetapi memaparkan fakta-fakta yang ada. "Penelitian kualitatif merupakan aktivitas/proses memahami hakikat fenomena dengan latar alamiah, dengan berporos pada data deskriptif yang disediakan dengan menggunakan teknik triangulasi untuk dianalisis sehingga menghasilkan pemahaman yang holistik berdasarkan perspektif sesuai dengan konteksnya" (Muhammad, 2011:31). "Metode kualitatif ini disebut metode artistik, karena proses penelitian lebih bersifat seni (kurang terpola) yang disebut sebagai metode interpretatif karena data hasil penelitian lebih berkenaan dengan interpretasi terhadap data yang ditemukan di lapangan" (Sugiyono, 2013:7). "Penelitian kualitatif adalah peneliti yang dilakukan pada 
kondisi objek yang alami, peneliti dengan instrumen kunci, teknik pengumpulan data dilakukan secara gabungan, data yang dihasilkan bersifat deskriptif dan analisis dapat dilakaukan secara induktif dan penelitian ini lebih menekankan makna dari pada generalisasi" (Sedarmayanti, dkk. 2011:33).

Metode yang digunakan dalam penelitian ini adalah metode deskriptif kualitatif. Metode ini akan menggambarkan objek yang sesuai dengan apa adanya mengeai bentuk penggunaan singkatan dan akronim dalam Berita Kriminal Koran Harian Tribun Jambi pada Bulan Maret 2019.

Data adalah bahan yang dijadikan dasar kajian penelitian. Data sangat penting dimiliki karna menjadi dasar suatu kajian dalam penelitian. Data adalah bahan yang digunakan dalam menganalisis sebuah penelitian, data merupakan sumber informasi yang akan diseleksi sebagai bahan analisis (Siswantoro, 2010:70). Data dalam penelitian ini berupa lalimat-kalimat yeng mengandung akronim atau singkatan yang terdapat dalam berita kriminal koran harian Tribun Jambi pada bulan Maret 2019. "Sumber data merupakan asal-usul dari apa, siapa, dan dari mana data diperoleh" (Muhammad, 2011:167). Dalam penelitian data diperoleh dari koran harian Tribun Jambi yang terbit pada Bulan Maret 2019.

"Teknik pengumpulan data merupakan langkah yang paling strategis dalam penelitian, karena tujuan utama dari penelitian adalah mendapatkan data" (Sugiyono, 2013:224). Teknik pengumpulan data dalam penelitian ini dilakukan melalui: dokumentasi, observasi, studi pustaka, Adapun teknik anaslisis data dilakukan menggunakan teknik kajian isi yang difokuskan untuk analisis proses pembentukan singkatan dan akronim yang terkandung dalam berita kriminal koran harian Tribun Jambi pada bulan Maret 2019.

\section{HASIL DAN PEMBAHASAN Hasil Penelitian}

Berdasarkan hasil analisis data yang telah dilakukan, maka dapat dideskripsikan proses-proses pembentukan singkatan dan akronim sebagai berikut. Dari 16 bentuk akronim menurut para ahli, hanya terdapat 4 bentuk akronim yang ditemukan dalam berita kriminal koran harian Tribun Jambi pada bulan Maret 2019, dan 1 bentuk singkatan. Ketiga bentuk akronim itu ialah bentuk akronim pengekalan huruf pertama tiap komponen, pengekalan dua huruf pertama tiap komponen, bentuk akronim pengekalan tiga huruf pertama tiap komponen, dan bentuk akronim pengekalan berbagai huruf dan suku kata yang sukar dirumuskan, dan pada bentuk singkatan yaitu pengekalan huruf pertama tiap komponen.

1. Penggunaan bentuk singkatan pengekalan huruf pertama tiap komponen. Terdapat 51 kutipan yang termasuk dalama bentuk singkatan ini. Huruf yang dikekalkan adalah huruf pertama dari tiap komponen dalam suatu frasa Penulisan pada bentuk ini menggunakan huruf kapital semua.. Bentuk singkatan ini hampir ditemukan pada setiap berita kriminal pada koran harian Tribun Jambi pada bulan Maret 2019.

2. Penggunaan bentuk akronim pengekalan huruf pertama tiap komponen. Pada berita kriminal koran harian Tribun Jambi bulan Maret 2019, hanya ditemukan 2 bentuk akronim yang termasuk kedalam bentuk ini. 
3. Penggunaan bentuk akronim pengekalan dua huruf pertama tiap komponen. Dalam berita kriminal koran harian Tribun Jambi pada bulan Maret 2019 hanya ditemukan 7 kutipan. Pemendekkan yang dilakukan meliputi pemendekkan pada dua huruf pertama pada kata.

4. Penggunaan bentuk akronim pengekalan tiga huruf pertama tiap komponen. Pengambilan tiga huruf pertama yang dilakukan pada tiap kata. Dalam berita kriminal koran harian Tribun Jambi pada bulan Maret 2019, hanya ditemukan 10 kutipan.

5. Penggunaan bentuk akronim pengekalan berbagai huruf dan suku kata yang sukar dirumuskan. Pengekalan berbagai huruf dan suku kata yang tidak beraturan. Pada bentuk ini hanya mementingkan bunyi yang enak didengar dan mudah diucapkan saja. Dalam berita kriminal koran harian Tribun Jambi pada bulan Maret 2019, ditemukan 12 kutipan.

\section{Pembahasan}

\section{Proses Bentuk Singkatan}

Singkatan merupakan proses pemendekkan yang berupa huruf atau gabungan huruf, baik yang dieja huruf demi huruf. Berdasarkan pendapat dari Kridalaksana bahwa terdapat 16 jenis singkatan, namun dalam berita kriminal koran harian Tribun Jambi pada bulan Maret 2019 hanya terdapat 1 bentuk dari 16 bentuk singkatan tersebut, yaitu pengekalan huruf pertama tiap komponen.

Berikut ini merupakan beberapa contoh kutipan serta penjelasan dari pengekalan huruf pertama.
Kutipan 1

"Operasi pengejaran aparat terhadap kelompok kriminal bersenjata (KKB) di Kabupaten Nduga, Papua". (KHTJ:9, 2 Maret 2019)

Pada kutipan (1) tersebut, terdapat singkatan KKB yang termasuk dalam jenis pengekalan huruf pertama tiap komponen. Karena pada singkatan KKB tersebut terjadi pengambilan huruf awal kata yang merupakan kepanjangan dari kelompok kriminal bersenjata. Singkatan KKB terdiri dari tiga kata yaitu: 'kelompok', 'kriminal', 'bersenjata'.

Kutipan 2

"Pemerintah mulai melakukan gerakan Kartu Jambi Bugar (KJB)". (KHTJ:9, 2 Maret 2019)

$$
\text { Pada kutipan (2) tersebut, }
$$
singkatan terdapat singkatan KJB yang termasuk dalam jenis pengekalan huruf pertama tiap komponen. Karena pada singkatan KJB tersebut terjadi pengambilan huruf awal kata yang merupakan kepanjangan dari kartu Jambi bugar. Singkatan $K J B$ terdiri dari tiga kata yaitu: 'kartu', 'jambi', 'bugar'.

\section{Proses Bentuk Akronim}

Akronim merupakan proses pemendekkan yang menggabungkan huruf atau suku kata yang ditulis dan dilafalkan sebagai sebuah kata. Berdasarkan pendapat dari Kridalaksana (2010) bahwa terdapat 16 jenis akronim, namun dalam berita kriminal koran harian Tribun Jambi pada bulan Maret 2019 hanya terdapat 4 bentuk dari 16 bentuk singkatan tersebut, yaitu; pengekalan huruf pertama tiap komponen; pengekalan dua hurif petama tiap komponen; pengekalan tiga huruf pertama tiap komponen; dan pengekalan 
berbagai huruf dan suku kata yang sukar dirumuskan.

\section{Pengekalan Huruf Pertama Tiap \\ Komponen}

Berikut ini dijelaskan beberapa contoh kutipan serta penjelasan dari bentuk pengekalan huruf pertama tiap komponen.

Kutian 1

"Beberapa cabor olahraga di porwil, untuk kelolosan (PON) harus menjadi finalis, jadi mesti mendapatkan mendali emas dan perak". (KHTJ:9, 26 Maret 2019)

Pada kutipan 1 tersebut terdapat akronim PON yang termasuk dalam jenis pengekalan huruf pertama tiap komponen. Karena pada akronim PON terjadi pengambilan huruf awal kata yang merupakan kepanjangan dari pekan olahraga nasional. Akronim PON terdiri dari tiga kata yaitu 'pekan', 'olahraga', 'nasional'.

Kutipan 2

"Kejadian dilorong bandara RT 19 kelurahan legok, kecamatan danau sipin, pada tanggal 31 Desember 2017 pukul 13.00 (WIB). Jelas kasat Reskrim (Polres)”. (KHTJ:15, 26 Maret 2019)

Pada kutipan 2 tersebut, terdapat akronim WIB yang termasuk dalam jenis pengekalan huruf pertama tiap komponen. Karena pada akronim WIB terjadi pengambilan huruf awal kata yang merupakan kepanjangan dari waktu Indonesia barat. Akronim WIB terdiri dari tiga kata yaitu 'waktu', 'Indonesia', 'barat'.

\section{Pengekalan Dua Huruf Pertama Tiap Komponen}

Berikut ini merupakan beberapa contoh kutipan serta penjelasan dari bentuk pengekalan huruf pertama tiap komponen.

Kutipan 3

"Terdakwa dugaan korupsi pajero sport DPRD Merangin, Isnedi dituntut 1,5 tahun atau satu tahun enam bulan pada sidang pengadilan tindak pidana korupsi (Tipikor)”. (KHTJ: 04, 25 Maret 2019)

Pada kutipan 3 tersebut, terdapat akronim tipikor yang termasuk dalam jenis pengekalan dua huruf pertama tiap komponen. Karena pada akronim tipikor terjadi pengambilan dua huruf awal kata yang merupakan kepanjangan dari tindak pidana korupsi. Akronim tipikor dibentuk dengan pengekelan dua huruf tiap komponen yaitu /ti/, /pi/, /kor/. Dua huruf awal kata pertama /ti/ dari kata tindak, dua huruf awal pada kata kedua /pi/ dari kata pidana, dan tiga huruf awal pada kata ketiga /kor/ dari kata korupsi. Jadi, akronim tipikor merupakan kependekan dari tindak pidana korupsi.

Kutipan 4

"Perkara dugaan pelanggaran pemilu (Caleg) DPR RI, Rahmat Derita ternyata tidak berlanjut kepersidangan, hal ini di sampaikan oleh pihak kejaksaan negeri Jambi”. (KHTJ:11, 25 Maret 2019)

Pada kutipan 4 tersebut, terdapat akronim caleg yang termasuk dalam jenis pengekelan dua huruf pertama tiap komponen. Karena pada akronim caleg terjadi pengambilan dua huruf awal kata yang merupakan kepanjangan dari calon legeslatif. Akronim caleg dibentuk dengan pengekalan dua huruf tiap komponen yaitu /ca/, /leg/. Dua huruf awal kata pertama /ca/ dari kata caleg, 
dan tiga huruf awal pada kata /leg/ dari kata legislatif.

Kutipan 5

"Beberapa cabang olahraga (Cabor) di porwil, untuk kelolosan ke PON harus menjadi finalis, jadi mesti dapat mendali emas dan perak". (KHTJ:15, 25 Maret 2019)

Pada kutipan 5 tersebut, terdapat akronim cabor yang termasuk dalam jenis pengekalan dua huruf pertama tiap komponen. Karena pada akronim cabor terjadi pengambilan dua huruf awal kata yang merupakan kepanjangan dari cabang olahraga. Akronim cabor dibentuk dengan pengekalan dua huruf tiap komponen yaitu /ca/, /bor/. Dua huruf awal kata pertama /cab/ dari kata cabang, dan dua huruf awal /orl dari kata olahraga. Jadi, akronim cabor merupakan kependekan dari cabang olahraga.

\section{Pengekalan tiga huruf pertama tiap komponen}

Berikut ini merupakan beberapa contoh kutipan serta penjelasan dari bentuk pengekalan tiga huruf pertama tiap komponen.

Kutipan 6

"Lebih kurang tiga jam dites urinenya di Dinas Perhubungan Tanjab Timur, BNNK angkut tiga pegawai (Dishub) diduga terindikasi mengkonsumsi narkotika". (KHTJ:10, 27 Maret 2019)

Pada kutipan 6 tersebut, terdapat akronim dishub yang termasuk dalam jenis pengekalan tiga huruf pertama tiap komponen. Karena pada akronim dishub terjadi pengambilan tiga huruf awal kata yang merupakan kepanjangan dari Dinas Perhubungan. Akronim dishub dibentuk dengan menggabungkan tiga huruf awal pada tiap kata yaitu /dis/, /hub/. Tiga huruf awal kata pertama /dis/ dari kata dinas, dan tiga kata huruf awal pada kata /hub/ dari kata perhubungan.

Kutipan 7

"Didapati membawa senjata tajam (Sejam), Ismail harus mendekam di balik jeruji besi". (KHTJ:16, 29 Maret 2019)

Pada kutipan 7 tersebut terdapat akronim sejam yang termasuk dalam jenis pengekalan tiga huruf pertama tiap komponen. Karena pada akronim sejam terjadi pengambilan tiga huruf awal kata yang merupakan kepanjangan dari senjata tajam. Akronim sejam dibentuk dengan menggabungkan tiga huruf awal pada tiap kata yaitu /sej/, /am/. Tiga huruf awal kata pertama /sej/ dari kata senjata, dan tiga kata huruf awal pada kata /jam/ dari kata tajam.

Kutipan 8

Kabupaten Tanjabbar merupakan satusatunya Kabupaten yang belum memilki gardu induk di Provinsi Jambi". (KHTJ:4, 30 Maret 2019)

Pada kutipan 8 tersebut terdapat akronim Tanjabbar yang termasuk dalam jenis pengekalan tiga huruf pertama tiap komponen. Karena pada kata Tanjabbar terjadi pengambilan tiga huruf awal kata yang merupakan kepanjangan dari Tanjung Jabung Barat. Akronim Tanjabbar dibentuk dengan menggabungkan tiga huruf awal pada tiap kata yaitu /Tan/, /jab/, /bar/. Tiga huruf awal kata pertama /Tan/ dari kata Tanjung, tiga kata huruf awal pada kata /Jab/ dari kata Jabung tiga kata huruf awal pada kata /bar/ dari kata Barat. 


\section{Pengekalan berbagai huruf dan suku kata yang sukar dirumuskan}

Berikut merupakan beberapa contoh kutipan serta penjelasan dari pengekalan huruf dan suku kata yang sukar dirumuskan.

Kutipan 11

"Memang ada temuan mayat tersebut, dugaan sementara dia punya penyakit magh kronis dan sesak nafas, kata (Kapolsek)". (KHTJ:10, 29 Maret 2019)

Pada kutipan 11 tersebut terdapat akronim kepala kepolisian sektor (Kapolsek) di bentuk adanya pengekalan berbagai huruf dan suku kata yang sukar dirumuskan. Sehingga pada akronim ini hanya mementingkan bunyi yang enak di dengar saja.

Kutipan 12

"Sesuai UU Nomor 23 orang asing difasilitasi dengan kartu identitas. Kartu identitas ini terbagi atas dua macam yakni kartu identitas tetap (KITAP) dan kartu identitas sementara (KITAS)", (KHTJ:9, 30 Maret 2019)

Pada kutipan 12 tersebut terdapat akronim kitap di bentuk adanya pengekalan berbagai huruf dan suku kata yang suka dirumuskan. Akronim ini hanya mementingkan bunyi yang enak di dengar saja. Jadi, akronim kitap merupakan kependekan dari Kartu Identitas Tetap.

\section{Kutipan 13}

"Sesuai UU Nomor 23 orang asing difasilitasi dengan kartu identitas. Kartu identitas ini terbagi atas dua macam yakni kartu identitas tetap (KITAP)dan kartu identitas sementara (KITAS)"(KHTJ:9, 30 Maret 2019)
Pada kutipan 13 tersebut, terdapat akronim kitas di bentuk adanya pengekalan berbagai huruf dan suku kata yang sukar dirumuskan. Akronim ini hanya mementingkan bunyi yang enak di dengar saja. Akronim kitas merupakan kependekan dari Kartu Identitas Sementara.

\section{SIMPULAN}

Berdasarkan hasil penelitian dan pembahasan yang telah dijabarkan, dapat disimpulkan bahwa dalam berita kriminal koran harian Tribun Jambi pada bulan Maret 2019 ditemukan 4 bentuk akronim dari 16 bentuk akronim yang dikemukakan oleh ahli, dan 1 bentuk singkatan, Keempat akronim tersebut yaitu: penggunaan bentuk akronim pengekalan huruf pertama tiap komponen, sebanyak 2 kutipan; penggunaan bentuk akronim pengekalan dua huruf pertama tiap komponen, sebanyak 7 kutioan; penggunaan bentuk akronim pengekalan tiga huruf pertama tiap komponen, sebanyak 10 kutipan; dan penggunaan bentuk akronim pengekalan berbagai huruf dan suku kata yang sukar dirumuskan,sebanyak 12 kutipan serta bentuk singkatan berupa pengekalan huruf pertama tiap komponen sebanyak 51 kutipan.

\section{SARAN}

Berdasarkan simpulan di atas maka, dapat dikemukan beberapa saran sebagai berikut.

1. Disarankan kepada para jurnalis surat kabar Tribun Jambi untuk dapat menuliskan singkatan dan akronim secara baik dan benar.

2. Disarankan kepada guru bahasa dan sastra Indonesia di sekolah dapat menjadikan berita-berita koran yang menggunakan singkatan dan akronim sebagai media pembelajaran akronim 
di sekolah agar siswa dapat menuliskan penulisan singkatan dan akronim dengan baik dan benar.

3. Disarankan bagi mahasiswa agar dapat melakukan penelitian lanjut yang sejenis dengan kajian yang berbeda.

\section{DAFTAR PUSTAKA}

Koran Harian Tribun Jambi. Edisi Maret (2019).

Kridalaksana, Harimurti. (2010). Pembentukan Kata dalam Bahasa Indonesia. Jakarta: Gramedia Widiasarana Indonesia Muhammad. (2011). Metode Penelitian Bahasa. Yogyakarta: Ar-ruzz

Ramlan, M. 2001. Morfologi Suatu Tinjauan Deskriptif. Yogyakarta: Karyono Rahima. A dan M. Juanda (2019). Bentuk Nomina Bahasa Melayu Jambi di Desa Peninjau Kecamatan Batin II Pelayang Kabupaten Muaro Jambi Provinsi Jambi (kajian Morfologi).Aksara: Jurnal Ilmiah Pendidikan Bahasa dan Sastra Indonesia Vol. 3 No. 1 April 2019 http://Aksara.unbari.ac.id/index.p hp/aksara E-ISSN:2597-6095

Rofii, Afif. dan Franscy. (2018). The Development of Contextual-Based Texbook on Morphological Process in Faculty of Teachers Training and Education Batanghari University Jambi. The Asian ESP Journal. Volume 14 Issue 2 Juli 2018. ISSN 2206-0979. https://www.asian-espjournal.com/2018/volume-14issue-2-july-2018/

Rofii, Afif. dan Hasibuan, Rizka Rani. (2019) Interferensi Bahasa Batak Mandailing dalam Tuturan Berbahasa Indonesia Pada Acara
Parpunguan Masyarakat Mandailing Kota Jambi. Aksara. aksara.unbari.ac.id/index.php/aksar a/article/download/94/50.

Sedarmayanti, Hidayat, dan Syarifudin. (2011). Metodologi Penelitian. Bandung: Mandar Maju.

Siswantoro. (2010). Metode Penelitian Sastra. Surakarta: Pustaka Pelajar. Sugiyono. (2009). Metode Kuantitatif, Kualitatif. Bandung: Alfabeta Bandung

Widarmanto, Thahjono. (2015). Pengantar Jurnalistik Panduan Awal Penulis dan Jurnalis. Yogjakarta. Araska Publisher. 